\title{
Effects of the Post-Relocation Support Policy on Livelihood Capital of the Reservoir Resettlers and Its Implications- A Study in Wujiang Sub-Stream of Yangtze River of China
}

\author{
Yuangang $\mathrm{Xu}^{1}$, Guoqing Shi ${ }^{1,2}$ (1) and Yingping Dong ${ }^{3,4, *}$ \\ 1 National Research Center for Resettlement, Hohai University, Nanjing 211100, China; \\ xuyg2001@163.com (Y.X.); gshi@hhu.edu.cn (G.S.) \\ 2 School of Public Administration, Hohai University, Nanjing 211100, China \\ 3 School of Geography \& Environmental Science, Guizhou Normal University, Guiyang 550001, China \\ 4 State Engineering Technology Institute for Karst Desertification Control of China, Guiyang 550001, China \\ * Correspondence: dongyingping2012@foxmail.com; Tel.: +86-13511903027
}

Citation: Xu, Y.; Shi, G.; Dong, Y. Effects of the Post-Relocation Support Policy on Livelihood Capital of the Reservoir Resettlers and Its Implications-A Study in Wujiang Sub-Stream of Yangtze River of China. Sustainability 2022, 14, 2488. https://doi.org/10.3390/su14052488 Academic Editor: Vida Maliene

Received: 19 January 2022 Accepted: 18 February 2022 Published: 22 February 2022

Publisher's Note: MDPI stays neutral with regard to jurisdictional claims in published maps and institutional affiliations.

Copyright: (C) 2022 by the authors. Licensee MDPI, Basel, Switzerland. This article is an open access article distributed under the terms and conditions of the Creative Commons Attribution (CC BY) license (https:// creativecommons.org/licenses/by/ $4.0 /)$.

\begin{abstract}
Hydropower energy is a clean alternative energy that has less impact on global climate change than fossil energy. However, the subsequent displacement and resettlement caused by dam construction is a global challenge perplexing the displaced population and the stability of the local socio-economic system. Without proper reconstruction and rehabilitation, the resettlers were highly risked in impoverishment. The Chinese government has formulated and implemented the postrelocation support (PReS) policy for reservoir resettlement and has continuously supported the resettlers to improve their livelihoods and socio-economic conditions since 2006. This paper focus on the 20 years dimension before and after policy formation, tests the variation of resettlers' livelihood capital and explores the effectiveness of the PReS policy and its blank spots based on a survey of 360 affected households by three big hydroelectric dams in China. The results show that reservoir resettlers would have caused the overall decline of resettlers' livelihood capital. The prominent problem is that the reduction of land resources and population relocation leads to the changes of resettlers' livelihood diversification and lifestyle change, which puts forward new requirements for the improvement of job skills and personal capability; the policy plays a significant role in rapidly improving the social, economic, and physical assets of resettlers in the early stage of reservoir resettlement; from the time scale of 15 years of policy implementation, the resettlement policy has an obvious slow-release effect on making up for the improvement of natural resources development and human capital; there are still blank spots in the current resettlement policy. Therefore, it is necessary to adjust and extend the policy for specific groups of people.
\end{abstract}

Keywords: reservoir resettlement; resettlers; livelihoods capital; post-relocation support (PReS)

\section{Introduction}

Hydroelectricity, as a type of renewable energy, is a good replacement for fossil energy because it produces less environmental pollution and reduced impacts on global climate change [1]. Currently, China ranks first in the world in both reservoir numbers and hydropower installation capacity [2,3]. Thus, 1.4 billion Chinese have already owned 98,500 hydropower stations [4]. As one of the by-products, there have resulted in 24.9 million resettlers up to date since 1949 due to the reservoir construction [5]. Major construction was carried out during the first 30 years after the founding of PRC (1949), the new China. In this period, the total number of constructed reservoirs has surged from 1200 to more than 83,000, and 16.89 million people have been displaced and relocated accordingly [6]. It appeared a booming tendency between 1949 and 1979. Because of the hydrology variation and other social and natural reasons, many small dams do not function well. Thus, after the 1980s, some large-medium-sized dams were arranged and constructed. 
Consequently, eight million resettlers were relocated from 1980 to 2020. Still, there are more than three million who will be relocated in the near future to China.

Since the resettlement has comprehensive impacts on local societies, economics, and environments in the long run, if their incomes were not restored and socio-economic characters were not 'rehabilitated' or managed properly before the close of the dam construction period, even with policies and monitoring mechanisms, the vast majority of the normal resettler population would be risked by impoverishment [7-9]. What happened previously in India has proved this assumption. India has similarly 20 million involuntarily displaced people caused mainly by development program requirements during the four decades from the 1950s to the 1990s. According to the documents, 75\% of India's displaced people have confronted impoverished issues after the resettlement due to their unstable incomes and unsustainable livelihoods [10-13]. These lessons were also happened in Asian countries $[14,15]$ and other countries globally $[16,17]$.

World Bank and experts have realized the above issues and tried to mitigate them since the 1980s. Different approaches have been devoted to addressing and solving such issues regarding income decrease and other impoverishment risks for development induced displacement and resettlement (DIDR) through the involuntary resettlement policies in World Bank China [18-20] and India [12]. The policies, standards, rules, norms, theories, methodologies, models in the land acquisition and resettlement survey, resettlement planning, implementation, monitoring have been studied and developed since the 1990s [21-29]. The Impoverishment Risk and Reconstruction (IRR) model was developed by Michael Cernea [30,31] and applied in the projects financed by International Finance Institutions (IFIs) in both developed and developing countries [12,15,32-34]. The academic researchers have discovered many reasons for impoverishment risks after DIDR, such as underestimated losses in physical and socio-economic, unfair compensation, lower and lack of reconstruction and rehabilitation standards for resettlers, in short of natural resources and sustainable livelihoods, serious and systematic destructiveness in the socio-economicculture system of affected families and communities, poor governance and management, weakness in the responsible institution and capacity absence of legality, lack of rules and regulations, etc.

Some models have been derived and developed, including Cernea's IRR model [30], Scudder and Colson's "stage" model [35,36], Downing and Garcia-Downing's "Routine/Dissonant Culture" and psycho-socio-culture model [37], de Wet's spatial and complexity model [38], Shi's five-stages resettlement system evolutionary model [39,40], nature resources conversion model [39,40], Shi and Shang's land asset securitization model [41], and Zhang's relative deprivation model [42], etc. Many new approaches were proposed and implemented world-wide, such as resettlement legislation [43], investment-impetus [44], resettlement development [45], benefit-sharing [46-53], land asset securitization [1], policyplan-implementation management [54-57], stakeholders' participatory development and community engagement [58-60], social stability risk assessment [61], environment and social impact assessment and management (ESIAM) [62,63]. However, all these types of research are still on the way. Among these, sustainable livelihoods and their reconstruction are one of the hottest topics. Livelihood capital analysis of all the models and researches have pushed national authorities to think about supporting activities after the relocation as suggested by the World Bank and other NGOs.

Similar to other countries that have involuntary relocation for development projects, China has serious post-relocation issues, too [64-66]. Limited by financial budgets and knowledge accumulation of the resettlement process, the central government was unable to strengthen the supervision process and continuously support the resettles after their relocation before the 1980s, which constituted many remaining legacies for local societies and potentially risked resettlers' livelihood and development opportunities in the long turn [64-66]. Until the mid-1980s, the concepts of social impact assessment and sustainable livelihood had been introduced to China, and this situation had changed afterward. Experts from World Bank helped to build a series of bilateral cooperation and 
joined membership. Since then, the China government has started to promote the long-term development-oriented resettlement and strengthened the management of resettlement planning involving compensation standards setting, resettlement process monitoring, execution process management, and the post-relocation support (PReS) policy [65-67].

In China, many efforts have been devoted by the government to improve the situation of reservoir resettlers after resettlement in recent years. In the time of 2006, two important documents over post-relocation problems were issued by the State Council of China. They are "Opinions on improving the post-relocation support policy for the resettlement of large to medium-sized reservoirs" [65] and "The regulations on compensation methods under land acquisition and resettlement for large to medium-sized water conservancy and hydropower projects" [66]. According to these, 25.02 million registered rural resettlement people from those large or medium-sized reservoirs were designed to be continuously supported individuals, and their livelihood and development would be covered by the policy for 20 years [65-67]. Through promulgation and implementation of PReS, the government tried to improve the living condition and to ensure resettlers' personal rights and sustainable livelihood or livelihood capital balance in the long run. They have been accepted to apply in the infrastructures globally [68].

In other words, PReS aims at improving sustainable livelihood capital. It is agreed that first, sustainable development is to develop without harming the future use of natural resources [69-71]. To ensure the sustainable livelihood of resettlers means to restore, maintain, or increase the capacity, the asset value of locals, and their rights to survive and develop without harming cross-generation use of natural resources. Since the late 1990s, the UK's Department for International Development (DFID), the World Bank, and other international development and aid organizations, together with the Institutional of Developments in Sussex University, put forward the sustainable livelihood approaches and an analytic framework to solve the vulnerability of rural households in the process of poverty alleviation. This analytical framework emphasizes the impact of the external intervention on Farmers' livelihood capital, livelihood strategies, and livelihood outcomes. It breaks through the previous thinking of only livelihood outcomes involved, emphasizes environmental sustainability and social sustainability, and is widely used in international poverty alleviation projects. Among them, natural assets refer to natural resources development, farmland improvement, and ecosystem services; physical assets refer to the basic means of production and infrastructure construction for sustaining livelihood; human assets include personal knowledge, skills, ability, and health capacity; financial assets refers to the cash that farmers can control and raise, the loan that farmers can reach when need; social assets mainly refer to various social resources used in livelihood activities.

However, a systematic analysis has not yet been implemented covering the effectiveness of sustaining livelihood according to the [72], which is seriously needed for the integrative management of registered resettlers, local societies, and local environments.

It is representative to select the Wujiang (WJ) River basin as an example to research the effectiveness of PReS policy specific for reservoir resettlers in China. The WJ River is the largest sub-stream on the south bank of the upper stream of the Yangtze River, one of the two mother rivers of China. It originates from the eastern part of the Wumeng Mountain region in Weining County is the largest river in Guizhou Province. The total length of the WJ River is $1050 \mathrm{~km}$, with a height difference of $1787.46 \mathrm{~m}$, and covers a total river basin area of $87,900 \mathrm{~km}^{2}$. The WJ basin spans 46 counties and cities in Yunnan, Guizhou, Chongqing, and Hubei provinces. Since $80 \%$ of WJ locates in Guizhou province, a province with the maximum amount of poverty population in China due to its fragile karst geographic landform and difficulty in natural resources utilization [73]. Up to 2020, the PReS policy has been launched and implemented in the WJ basin for 15 years, which has special importance in ecologically vulnerable areas such as the Guizhou province, China, where land is generally less productive. Meanwhile, karst fragility causes a massive poverty distribution historically. Before the year 2020, as much as 9.23 million population in Guizhou province had gained less than 1.9 U.S dollars per day, which is far below the 
absolute poverty line (World Bank, 2015). Reversely, the massive poverty phenomenon had imposed negative impacts on the environment and worsened local ecosystems. Evidently, in such an environmentally fragile zone, it is extremely hard to sustain naturally in the long term with previous land-dependent types of livelihoods.

This case study on the livelihood capital variation of reservoir resettlers' under the PReS policy at three critical time-points in three selected reservoir resettlement regions, the most typical counties in Guizhou province near WJ River Basin. Combining the results from the questionnaire in 2020, accumulated survey results in 2010 and 2000, and local statistical documents, this paper aims to find out the mechanism that this policy helped resettlers improve their livelihood capital in a 15-years span, which could provide a preliminary reference for the effectiveness analysis of and also problem-finding for the PReS policy.

\section{Materials and Methods}

\subsection{Description of the PReS Policy}

Since historical issues succeed from the reservoir resettlement mainly associated with weak infrastructure, limited arable area, rural poverty, low educational level, socially disconnected of resettlers, etc., to address such types of issues, the executive meeting of the State Council passed the revised regulations on "Land acquisition compensation and resettlement for large and medium-sized water conservancy and hydropower projects in principle" and the agreement on initiating and improving the PReS regulation for reservoir resettler in 2006. In April 2006, the CPC Central Committee listened to the report on reservoir resettlement and made major decisions on improving the reservoir resettlement policy. On 17 May 2006, the State Council issued the "Opinions on Improving the PReS Policy for Large or Medium-sized Reservoirs" [65]. This document clearly proposed that continuous support should cover all large or medium-sized reservoirs related to resettlement populations. It should last for 20 years in terms of cash subsidy (600 RMB/person/year) and project-based development funds support, which were called the post-relocation support policy or the PReS policy.

The PReS is a government-initiative yet resettler-centered policy that determined 20-years-lasting support covering many aspects of resettlers' livelihood. The implementation of this policy tries to provide opportunities to sustain the living ways, to alleviate the impoverishment risks, and to help build balanced livelihood capital of the reservoir resettlers. Practically, weak infrastructure and lack of personal skill were prominent problems addressed, which created difficulties for resettlers in improving their livelihood capital. The PReS policy provides funds for infrastructure construction and project-based development opportunity to improve living conditions and investment conditions for resettlers. Through skill training or educational improvement, some resettlers are gradually able to connect new societies with their elevated personal values. Gradually, some run their own business, and some work nearby as labor for salaries. With the low-interest loan, those who run a small business or plant economic vegetables attained the opportunities to enlarge their annual income. The PReS policy has also provided normative protections in the conflict consolation or social adaption of involuntary resettlers. This is important when resettlers encounter critical disruption, temporary distress, or family shock moments, such as health issues, incidents, and so on.

There are 2 main financial supporting funds sources. First is submitted by the enterprise owners in the WJ river basin in terms of the annual share of the 0.008 yuan per unit power of hydroelectricity. The second is the 0.0065 yuan per unit power of hydroelectricity collected from the urban citizens. The enterprise-owner source of funds is collected and distributed by the provincial government, and the citizen-sourced funds are collected and allocated by the central financial department of China. Therefore, each province receives its part of the funds according to the numbers of the resettlers annually. These supporting funds are planned and monitored as a whole by the Ecological Relocation Bureau of, for example, the Guizhou province. The total amount varies by year depending on the electricity consumption, and related provincial departments appropriate the funds 
mainly in two ways, as cash subsidies and project investment. A cash subsidy of $600 \mathrm{RMB}$ $(\approx \$ 94.32) /$ person/years allocated to each registered resettler. The rest funds are invested in development projects or basic infrastructure investment projects to improve local investment conditions or to develop projects that accommodate local resettlers as laborers or managers. Funds are also available to help resettlers with constructing houses, inner decoration, furniture, and daily used electricity.

According to the PReS policy, to ensure broad social support to the resettlement population, the central government helps to connect eastern-developed cities with westerndeveloping cities as sister-cities in the form of one-to-one or one-to-many ways to provide relatively stable job occasions to western farmers. Through which, resettlers not only owned the priority to be registered and recommended to a better-paid work opportunity but also gain the incentives and open-eyes to upgrade their skills and knowledge (human asset) to hold their new job or business management. Thus, their financial asset has improved accordingly, and their livelihood capital balance can be achieved in the new resettlement region.

There are also many social mediation organizations or non-governmental organizations that are encouraged to join in and help the resettlers improve their social integration to their new society, which is important to avoid marginalization and impoverishment. Otherwise, the information block and sense of presence vanishing may enlarge the possibility of impoverishment or emotional depression.

Even if it legally does not exist, in this paper, we treated both the $600 \mathrm{RMB}$ subsidies and the project-based development funds for some resettled families as the dividends of natural resources because these two sources of subsidies were received in practice by resettlers for their loss of land in the following 20 years.

\subsection{Description of Study Area}

WJ River [74-81], lining out the east of Yunnan-Guizhou Plateau of southwest China and lasting $1050 \mathrm{~km}$, is a sub-stream of the upper reaches of the Yangtze River (see Figure 1), which originated in Weining Yi-Hui-Miao Minority Autonomous County of Guizhou Province. More than $80 \%$ of the mainstream of WJ River is located in Guizhou province. The elevation differences between East and West are as high as $2124 \mathrm{~m}$, while the total annual runoff in the basin is 53.4 billion $\mathrm{m}^{3}$ per year, the average annual discharge of the estuary is $1609 \mathrm{~m}^{3} / \mathrm{s}$, which equals $92 \%$ of the second largest river of Yellow River Estuary in China. Therefore, the theoretical reserves of hydraulic resources are 10.23 million $\mathrm{kW}$, and 259 sites there can be developed to produce electronic power in the WJ basin. In practice, only around 40 medium-sized reservoirs on the main tributaries of the WJ basin have been planned to explore. Under the PReS policy, about 117,000 registered resettlement populations have gradually been supported since the year 2006 to support the reservoir resettlers and their community in the $\mathrm{WJ}$ river basin.

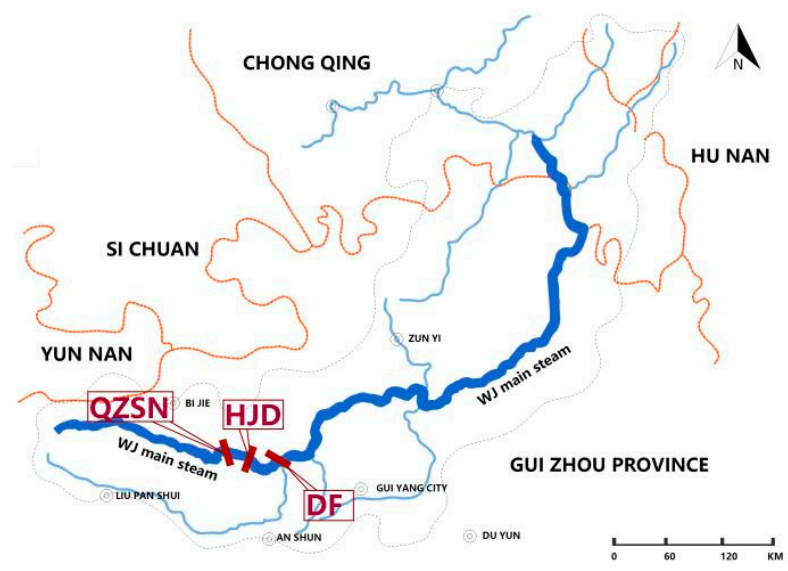

Figure 1. Distribution of 3 Surveyed Resettlement Region in WJ river stream. 
Three reservoir resettlement regions were selected as examples to survey in this paper (see Figure 1). The relocation of DF reservoir was finished in 1992, HJD finished around 2004, and QZSN, finished in 2011. The PReS policy fully covered DF and HJD region since 2006 ( $\approx 15$-years in 2020) and QZSN region since 2011 ( $\approx 10$-years in 2020 survey).

\subsection{A Framework for Sustainable to Monitor Livelihood of Reservoir Resettlers}

A livelihood is defined as sustainable if family assets and the livelihood capital are maintained or improved based on personal capacity improvement, capital accumulation, and activity involvement without undermining the natural resource basis [82-84]. "The Copenhagen Declaration" (1995) highlights the importance of employment opportunities to family livelihood capital which suggests the lifestyle change of the observed rural population. Here, we apply the DFID's (Department for the international development of British) sustainable livelihood framework and modify it (Figure 2) to describe the livelihood capital of reservoir resettlers in WJ river basin for stages before and after the post-relocation support (PReS) policy implementation.

Outcomes

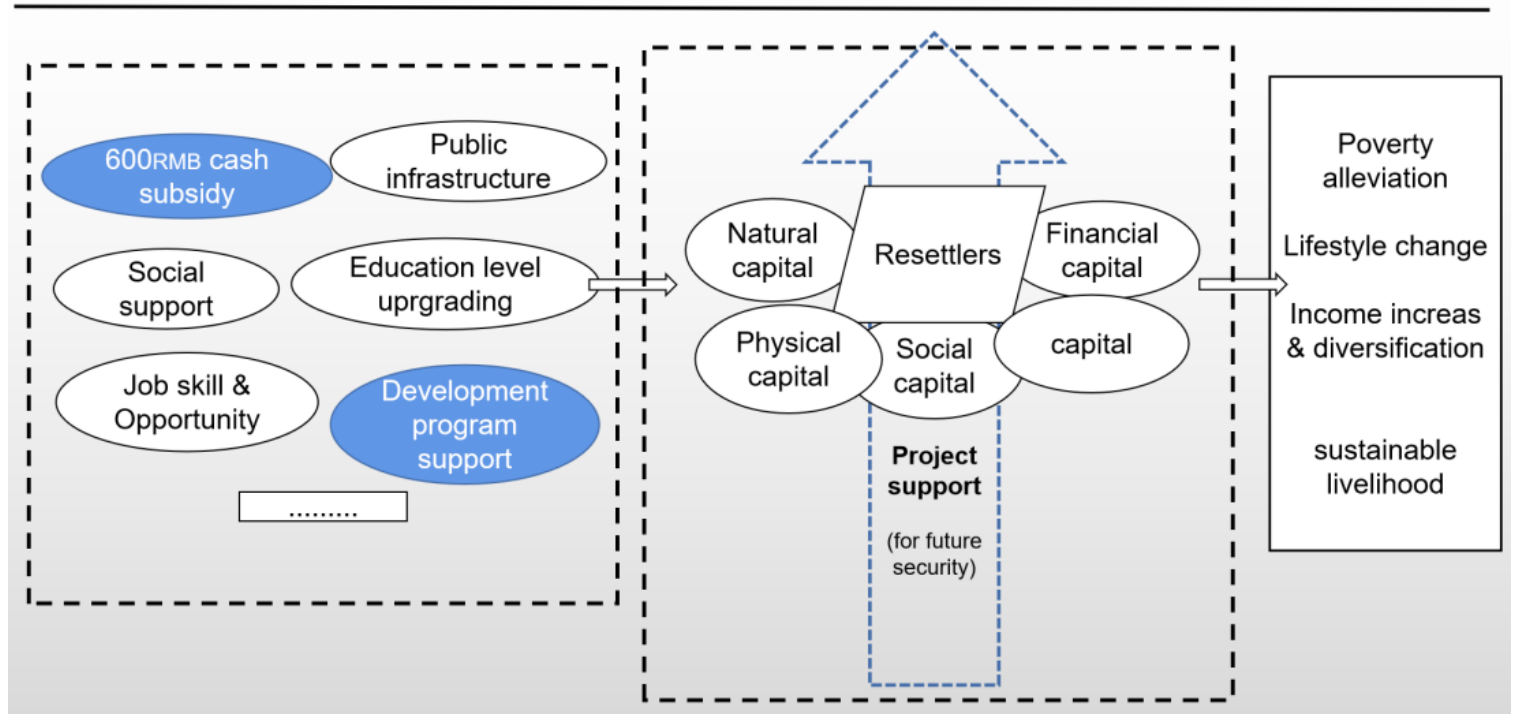

Figure 2. A framework for sustainable livelihood of reservoir resettlers.

Under this premise, livelihood capital in this study consists of 5 major components, which are natural, physical, social, human, and financial assets. Since the PReS policy encourage both direct support to resettlers via cash subside and multiple development programs support to improve their public facilities, living condition, livelihoods development, job and employment, social adaption and integration, living environment, etc. From a policy-making point of view, increasing the resettlers' sustainable livelihood capital is the key approach for improvement of the income and living conditions. The monitoring and evaluation of livelihoods capital and outcome variation of resettlers reveal the well-being/or worsen-off of resettlers' living and social-economic condition and goals achievement. Under current policy, the development programs support pathway of PReS act as a pull-force to balance livelihood in the long run through providing stable income and playing a driving role in the economic development of the whole community.

\subsection{Indicators Selection for Livelihood Assessment}

As stated in Section 2.3, a modified DFID framework is used to describe the sustainable livelihood capital of reservoir resettlers in the WJ river basin. The framework includes 5 assets and 13 secondary indicators. Five assets consist of livelihood capital in this study as the natural, physical, financial, human, and social assets. The secondary indicators of 
the natural assets include, for example, land resources, arable land area, water resources, and forest resources.

The rating scale method was used in the score of calivelihood capital. Resettlers' perceptions over each indicator were asked and classified into 3 types as "worsen, nonchange, better", "Yes-or-no" answers, and "annual income $>,=$, or < average income". Details are displayed in Table 1.

Table 1. Indicator selection for capital-assets.

\begin{tabular}{|c|c|c|c|c|}
\hline Capital-Asset & Principle Description & $\begin{array}{l}\text { Criterion for Individual } \\
\text { Principles }\end{array}$ & Indicators & Score \\
\hline Natural Assets & $\begin{array}{l}\text { Quantity and quality of } \\
\text { natural resources for } \\
\text { future use are maintained. }\end{array}$ & $\begin{array}{l}\text {-Land assets is improved } \\
\text { or not } \\
\text {-Water assets is improved } \\
\text { or not }\end{array}$ & $\begin{array}{c}\text { Land Resources } \\
\text { N1 } \\
\text { Arable land area } \\
\text { N2 } \\
\text { Water resources } \\
\text { N3 } \\
\text { Forest resources } \\
\text { N4 } \\
\text { Room decoration }\end{array}$ & $\begin{array}{c}\mathrm{SN}=\left(\mathrm{Ni}_{1}+\mathrm{Ni}_{2}+\mathrm{Ni}_{3}+\right. \\
\left.\mathrm{Ni}_{4}\right) / 4\end{array}$ \\
\hline Physical Assets & $\begin{array}{l}\text { Physical capital is } \\
\text { maintained or improved }\end{array}$ & $\begin{array}{l}\text {-House physical condition } \\
\text { is improved or not } \\
\text {-Infrastructure is } \\
\text { improved or not }\end{array}$ & $\begin{array}{c}\text { P1 } \\
\text { Room area } \\
\text { P2 } \\
\text { Infrastructure level. } \\
\text { P3 }\end{array}$ & $\mathrm{SP}=\left(\mathrm{Pi}_{1}+\mathrm{Pi}_{2}+\mathrm{Pi}_{3}\right) / 3$ \\
\hline Financial Assets & $\begin{array}{l}\text { Financing ability is } \\
\text { improved equitably }\end{array}$ & $\begin{array}{l}\text {-Financing ability is } \\
\text { improved or not } \\
\text {-Family revenue is } \\
\text { improved or not }\end{array}$ & $\begin{array}{l}\text { Financing channels } \\
\text { F1 } \\
\text { Family income } \\
\text { F2 }\end{array}$ & $\mathrm{SF}=\left(\mathrm{Fi}_{1}+\mathrm{Fi}_{2}\right) / 2$ \\
\hline Human Assets & $\begin{array}{l}\text { Ability to win added } \\
\text { value is improved }\end{array}$ & $\begin{array}{l}\text {-Education, work skill is } \\
\text { improved or not }\end{array}$ & $\begin{array}{c}\text { Education levels } \\
\text { H1 } \\
\text { Professional training } \\
\text { H2 }\end{array}$ & $\mathrm{SH}=\left(\mathrm{Hi}_{1}+\mathrm{Hi}_{2}\right) / 2$ \\
\hline Social Assets & $\begin{array}{l}\text { Social reciprocity is } \\
\text { maintained within local } \\
\text { systems }\end{array}$ & $\begin{array}{c}\text {-Trust towards other social } \\
\text { members } \\
\text {-Emergency or economic } \\
\text { shocks is buffered by } \\
\text { social reciprocity }\end{array}$ & $\begin{array}{c}\text { Kinship } \\
\text { S1 } \\
\text { Leader's supports } \\
\text { S2 }\end{array}$ & $\mathrm{SS}=\left(\mathrm{Si}_{1}+\mathrm{Si}_{2}\right) / 2$ \\
\hline
\end{tabular}

\subsection{Data Collection}

Both quantitative and qualitative analysis methods were used to ensure the systematic exploration of WJ river basin resettlement communities. In the year 2020 total of 360 families involving about 1800 persons were sampled and questioned, which equals nearly $7.0 \%$ of local relocated persons. A total of $20 \%$ of them were in-depth interviewed. The survey covers 3 resettlement regions of 3 related large to medium-sized reservoirs, as the DF, HJD, and QZSN reservoir basin to represent 25,681 registered resettlers in the WJ river basin in Guizhou province in April and May 2020.

Historic surveys regarding livelihood situations before and after the dam-caused relocation in 3 resettlement regions were referred to figure out the relocation impacts before and after relocation. Because the selected reservoir relocation was completed at 3 different times (see Section 2.2), historical documents of DF in 1992 and 2000, HJD in 1995 and 2000, and QZSN in 2015 and 2020 have been referenced.

To clarify the early effects of the PReS in reservoir resettlement regions, the historic data in 2000 was defined as "without policy", data in 2010 were defined as "with policy". Because these 3 resettlement regions are all located in the upper parts of the WJ mainstream (see Figure 1) and share many similarities in both spatial, political, and social-economic backgrounds [74,77,81]. Differences in resettlers' livelihood capital are assumed to be able to explain the inner mechanism of the PReS policy affecting resettlers' livelihood capital.

The historical policy performance documents in 2000 and 2010 of the DF region were referred to show the livelihood capital variation of resettlement groups without (6 years ahead) the PReS policy and with the policy (4 years after). Historic surveys regarding 
livelihood situations in 2000 (Without policy), 2010(5-years-after), 2015(10-years-after), and 2020 (15-years-after) in the DF region were referred to figure out the policy effects in timeline.

The research of cash subsidy's contributing to personal income aims at checking the value of 600 RMB every 10 years between 2000 to 2020 that involved the policy preparation stage (6-year-ahead), early stage of the policy implementation (4th-years-after), and the 15 th-years after implementation with exchange ratio in time, 600 yuan $\approx \$ 94.32$ in 2020 ; $\approx \$ 88.11$ in 2010 and $\approx \$ 72.55$ in 2000 .

\subsection{Data Analysis}

Combing qualitative and quantitative methods were used in this study. All the livelihood capital indicator score based on the perception and attitude of respondents to related indicators separately. Natural assets and income data refer to recorded data of resettlers covering arable land (family property) area, forest area (family property) area, land resources (available land via rent) area, and water resources (the assuming property within 20 years), annual income from the plantation, or working as labor, or rural business, etc.

\section{(1) The rating scale method}

Three levels of satisfactory degree for each indicator were used after the survey. The critical values of $0.33,0.66$, and 1.00 represented "the worsen, non-change, and better", respectively (Chen et al., 2016).

If the indicator was answered by yes or no, then "yes" marks 1 and "no" marks 0 (Chen, Zhu, Krott, and Maddox, 2013a; Chen et al., 2013b; Islam, Rahman, Asahiro, Sato, and Tani, 2014; Muangkaew and Shivakoti, 2005).

Statistic data of local income were used as a contrast value. By comparing the detailed income amount of each respondent to the contrast value $(\mathrm{CK})$, the income $>1.5$ times of the CK defines as good with a weight of 1.00; $1.5>X>1.0$ marks as an average level with a weight of $0.66 ;<1.0$ times of the CK denotes poor situation with a weight of 0.33 .

(2) 5 assets for livelihood pentagon

In this study, the livelihood pentagon is used to describe the livelihood capital balance of resettlers, including natural, physical, social, human, and financial assets. Data were analyzed regarding indicators livelihood capital accordingly (see Table 1). Each asset score equals the percentage of classified indicator's score. Five livelihood assets are defined to be the total score of a resettlers' livelihood capital.

$$
\begin{gathered}
\mathrm{A}_{\text {type } 1}=\text { worsen } \% * 0.33+\text { non-change } \% * 0.66+\text { better } \% * 1.00 \\
\mathrm{~A}_{\text {type } 2}=\mathrm{No} \% * 0.00+\mathrm{Yes} \% * 1.00 \\
\mathrm{~A}_{\text {type } 3}=\text { poor } \% * 0.33+\text { average } \% * 0.66+\operatorname{good} \% * 1.00
\end{gathered}
$$

A, livelihood asset; $\mathrm{X} \%$, the ratio of this class to the whole. (for details see Table 1 ).

\section{(3) Livelihood capital}

Five types of asset scores added together equal to a complete livelihood capital of a selected respondent as follows (Formula (4)). According to the setting, the full score of each asset of the livelihood capital is 1 . Therefore, the maximum score for livelihood of individual is 5 .

$$
\mathrm{LC}=\mathrm{AN}+\mathrm{AP}+\mathrm{AF}+\mathrm{AH}+\mathrm{AS}
$$

where, LC is livelihood capital; AN means natural asset; AP refers to physical asset; AF marks financial asset; $\mathrm{AH}$ is human asset; AS denotes social asset. 


\section{Results}

\subsection{The Impacts of Reservoir Resettlement}

The farmers' livelihood capital was surveyed in communities with or without the reservoir relocation in three representative resettlement regions alone WJ river basin in 2020 for DF, HJD, and QZSN reservoir. Livelihood pentagon (Figure 2) shows that firstly, the relocation has resulted in a shrinkage of overall livelihood capital, including a significant decline of natural assets in all survey sites, from about $0.43-0.58$ to about $0.23-0.34$ on average; a decrease in human assets from $0.45-0.48$ to $0.25-0.50$; and both social and financial assets sway.

While the overall trend of financial assets after resettlement was decreased from $0.36-0.46$ to $0.25-0.40$ in HJD and QZSN. Yet, it increased mildly in the DF region from 0.27 to 0.35 . Meanwhile, social asset variation displayed a similar trend that only in the DF region increased from 0.53 to 0.76 . In the other two regions, resettlers' social assets decreased from 0.76 to $0.66-0.71$ after resettlement.

The planning reports show that the ratio of local settlement was much higher in the DF region in the 1990s compared to HJD around the 2000s and in QZSN around the 2010s (see Figure 3). Figure 3 probably partly explains the different appearances of financial and social assets in the DF region.

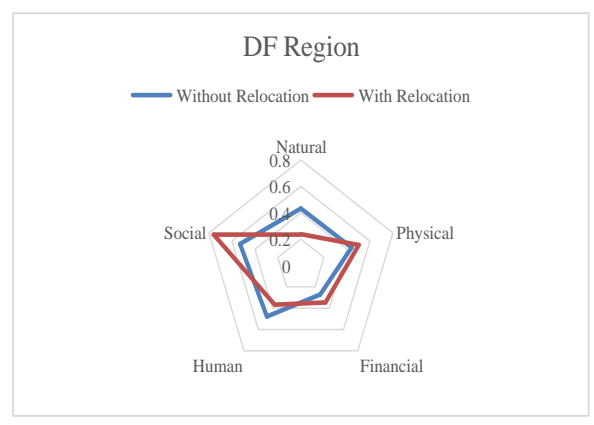

(a)

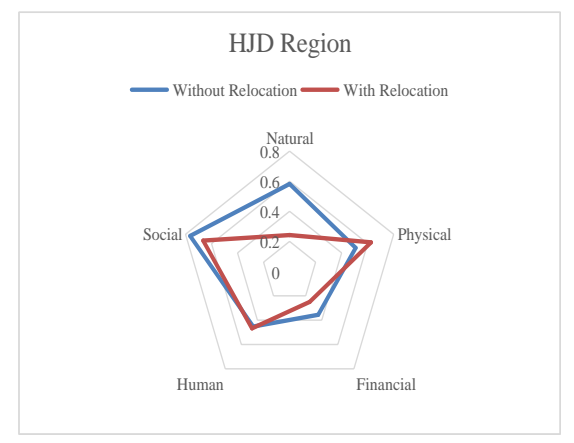

(b)

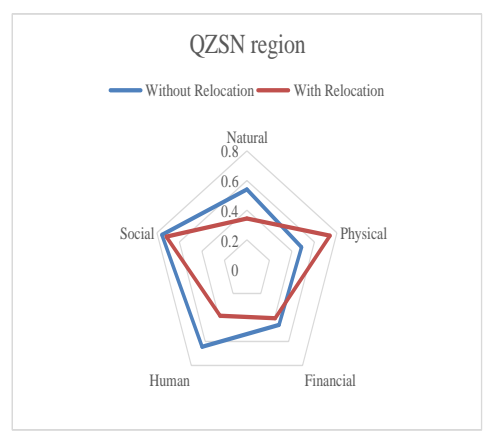

(c)

Figure 3. The Livelihood capital variation caused by relocation: (a) SZQ Region; (b) HJD Region; (c) QZSN Region.

Only the physical asset scores from $0.44-0.51$ before the relocation have upgraded to $0.50-0.74$ after relocation. This implies that after relocation, the government fulfilled the basic infrastructure construction very well and in time.

Considering the relocation types, Figure 4 tells that in the DF region, $40 \%$ of reservoircaused relocation is local resettlement, that is, the movement within the home village. This number in the HJD and QZSN is 11\% and 13\% separately, which is much less than in the DF.

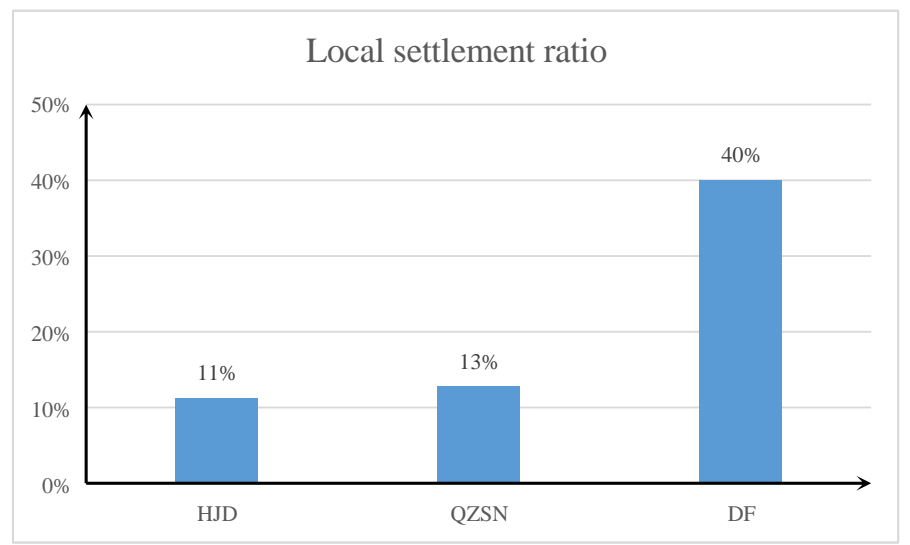

Figure 4. The Local settlement ratio. 


\subsection{Comparison between with or without the Policy}

Figure 5 tells that during the early stage, regarding $600 \mathrm{RMB}(\approx \$ 94.32)$ subsidies as an assumed dividend of water resources, all the natural assets turned to be increased from $0.45-0.55$ to $0.50-0.63$, and all the physical assets increased from $0.44-0.51$ to $0.50-0.62$ in the early stage of the implementation of PReS policy.

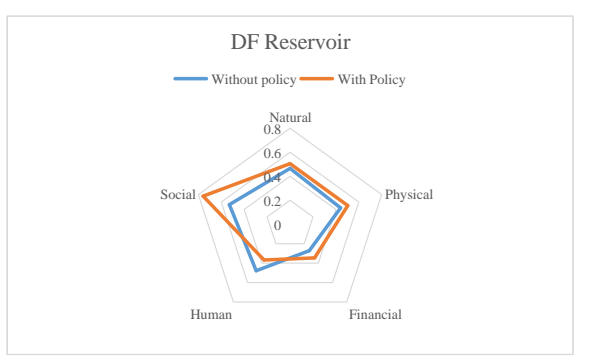

(a)

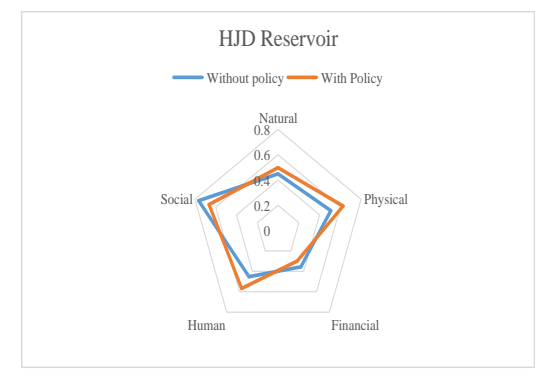

(b)

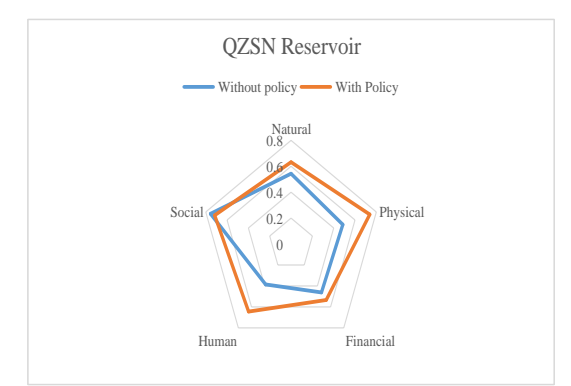

(c)

Figure 5. Impacts of the PReS policy on livelihood capital variation in resettlement region with or without: (a) SZQ Region; (b) HJD Region; (c) QZSN Region.

The overall trends of the financial, human, and social assets after the policy are increased from $0.27-0.46$ to $0.30-0.53,0.38-0.48$ to $0.37-0.57$, and $0.53-0.77$ to $0.67-0.87$, whereas each asset has an exceptional region in the above three resettlement regions. For example, the financial and social assets decreased in HJD with the policy than without policy; human assets decreased in the DF region after the implementation of the policy (see Figure 4).

Both results are understandable with the in-depth interviews. In HJD relocation, as high as $89 \%$ of resettlers choose to move to other villages, towns, cities, or provinces. During this process, they had experienced the initial stage of the housing-cost increasing and spent much more money on building new larger, and better houses than resettlers in the DF region five years ago. Which dramatically reduced their financial balance and risked them with social adaption difficulties in the resettlement region.

In the DF region, it is beyond the expectation that the human asset decreased after the implementation of policy. However, the in-depth interviews told that with the encouragement of the PReS, children in some resettlement families choose to enroll in a higher educational school/or university rather than to receive professional training, which reduced human asset scores temporarily.

\subsection{The Time Response of the PReS Policy on Local Livelihood Capital}

Based on the surveyed data in 2000, 2010, 2015, and 2020 in the DF region, Figure 6 told that there was a linear increase tendency for the livelihood capital variation in the past 15 years $\left(y=0.4285 x+1.9708, R^{2}=0.9646\right)$. 


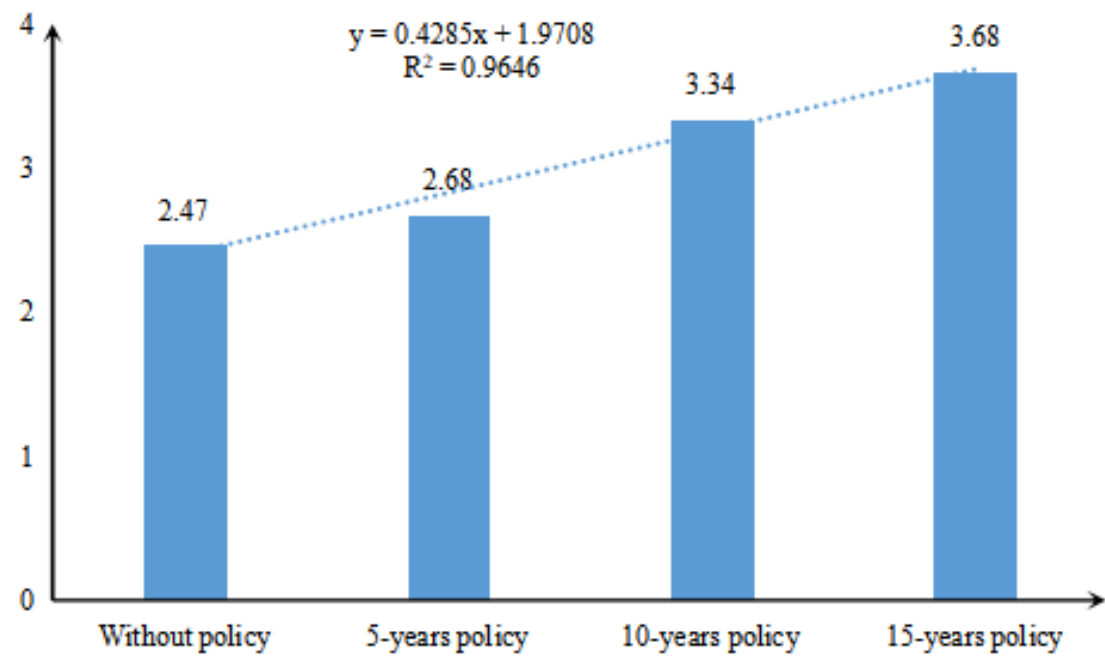

Figure 6. Total livelihood capital variation after the release of the PReS policy.

Table 2 shows that the social, human, and physical assets have increased gradually according to the pass of time with the emergence of the support policy. Physical assets have increased $59.56 \%$, and social assets increased $43.26 \%$ in the 5 th year after the relocation. After 15 years, physical assets have increased $110.76 \%$ compared to the years without the policy. At the same time, the social, human, and financial assets have increased $75.59 \%$, $69.67 \%$, and $62.26 \%$ than the year without the policy. However, the natural assets decrease from $41.95 \%$ in the 10 th year to $21.48 \%$ in the 15 th year.

Table 2. Variation of livelihood capital in the timeline.

\begin{tabular}{cccc}
\hline Livelihood Capital & 5th Year & 10th Year & 15th Year \\
\hline Natural & $8.46 \%$ & $41.95 \%$ & $21.48 \%$ \\
Physical & $59.56 \%$ & $94.23 \%$ & $110.76 \%$ \\
Financial & $27.31 \%$ & $50.18 \%$ & $62.26 \%$ \\
Human & $-23.12 \%$ & $18.55 \%$ & $69.67 \%$ \\
Social & $43.26 \%$ & $60.24 \%$ & $75.59 \%$ \\
Total livelihood & $8.59 \%$ & $35.33 \%$ & $48.94 \%$ \\
capital & & & \\
\hline
\end{tabular}

Yet the human assets show a $-23.12 \%$ increase in the 5 th year compared to the situation before the policy, and then slowly upgraded at the 10th year. Interestingly, human assets surged in the 15th year, which implies an accumulative effect of resettlers' offspring involved in the new educational system.

\subsection{Impacts of the PReS Policy on Family Livelihood Diversity}

Based on both the surveys and the in-depth interviews, financial asset increase is found to be the most difficult part, in the long run, to improve under the PReS policy. Hence, it constitutes the limiting factor for livelihood capital improvement. As stated in Table 1, the financial asset consists of income and financial loans. Since the utilization of financial loans is still very limited, in this part, we focus mainly on the impacts of PReS policy on the income of relocated families.

\subsubsection{Impacts of 600 RMB on Annual Family Income}

Figure 7 showed that in 2000, the annual income of $600 \mathrm{RMB}(\approx \$ 94.32$ in 2020$)$ was less than $10 \%$ of the annual income of $32.3 \%$ of individuals. Meanwhile, it accounted for $10 \sim 100 \%$ of $52.3 \%$ of personal income and twice of $15.4 \%$ of personal annual income. In other words, the money was not trivial in the year 2000 for up to $67.7 \%$ of rural individuals. In 2010 , for $54.4 \%$ of resettlers, the share of this money in annual income was less than 
$10 \%$. Compared to $32.2 \%$ of the population in 2000 , the proportion of $600 \mathrm{RMB}$ in personal income decreased significantly. Yet, it still was 10 100\% of the annual income of $34.5 \%$ population and more than $200 \%$ of the annual income for $11.1 \%$ of individuals.

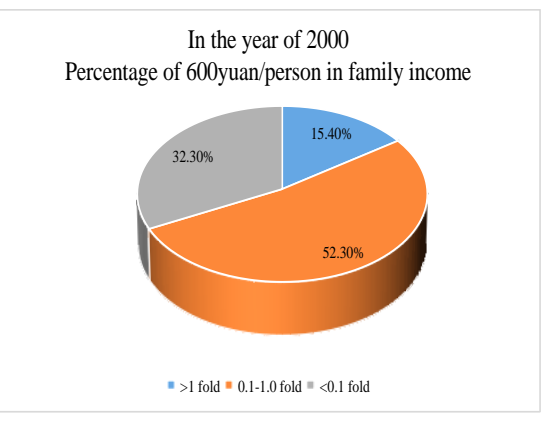

(a)



(b)

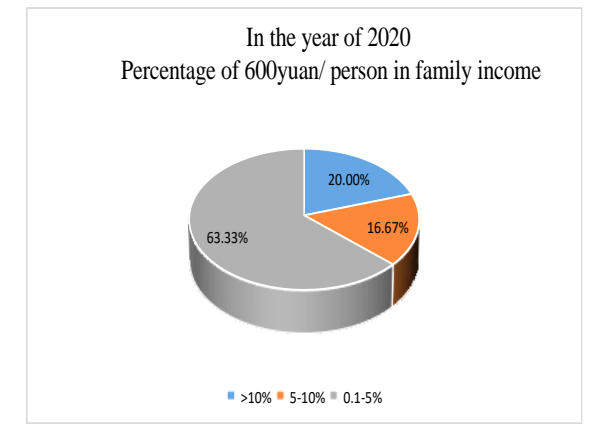

(c)

Figure 7. Percentage of $600 \mathrm{RMB} /$ person in family income: (a) In $2000(\approx \$ 72.55)$; (b) in $2010(\approx \$ 88.11)$; (c) in $2020(\approx \$ 94.32)$.

According to the PReS policy, since 2006, each resettler has received $600 \mathrm{RMB}$ /year for 20 years which is regarded as an assumed interest of water resources in this study. Currently, in the survey of 2020 , for $63.33 \%$ of the surveyed resettlement families, this amount occupies less than $5 \%$ of their family income averagely in the survey of 2020, which is trivia for their total financial assets.

\subsubsection{Impacts of the PReS Policy on Livelihood Diversity via Development Project}

With the PReS policy, the farming-dependent lifestyle of resettler families has changed to a diversified type which normally consists of two more dominant factors as business and labor. Figure 8 shows that before the policy, $58.33 \%$ of resettlement families relied on the one sourced income. After the policy, this number was reduced to $16.25 \%$, and as much as $85.75 \%$ of the resettlers have changed their lifestyle from farming-dependent to multiple-sourced under the supervision of the PReS policy.

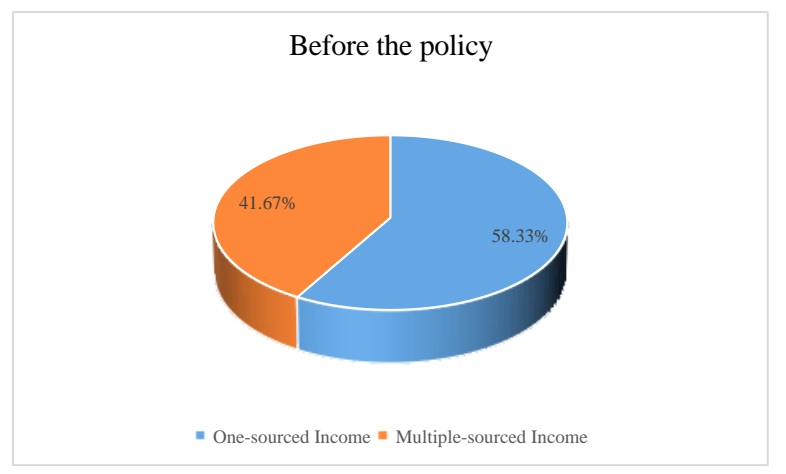

(a)

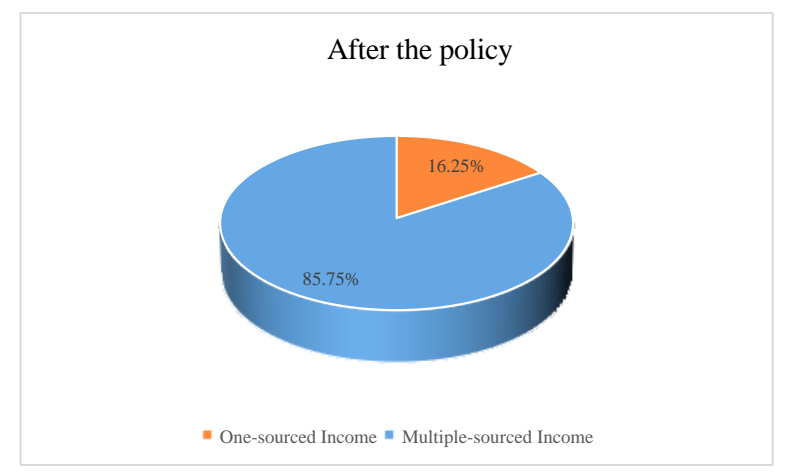

(b)

Figure 8. Impacts of the PReS policy on livelihood diversity (a) before the policy; (b) after the policy.

Considering the livelihood diversification, $86.63 \%$ of the family income is non-farming activities. Running a small business and working as laborers are dominant factors that occupied totally of $79.46 \%$ of the resettlers' income in the resettlement region. Among these, labor accounted for $50 \%$ and business for $29.46 \%$ of the income. The farming practice existed only $13.37 \%$ of the relocated population's income on average. 


\section{Discussion}

\subsection{Relocation's Impacts on the Livelihood Capital of Reservoir Resettlers}

The comparison of livelihood capital between with and without relocation shows that relocation resulted in a significant reduction of land, house, and other natural resources (see Figure 3) due to the reservoir inundation and related resettlement. House normally have been built in resettlement regions before move-in, yet the cropping land seems difficult to handle in some areas. For example, in Yina town of DF river region, resettlement region has limited available cropland area for exchange. Even some indigenous families spare a little available land for selling, the quality of which is not satisfied by resettlers. Consequently, the local settlement ratios in the three resettlements are all lower than $40 \%$, many resettler families choose to relocate into other townships or cities (see Figure 4).

This result is consistent with the trend reported in the literature. Document records show that the land re-allocation to resettlers in the rural area had been increasingly difficult since the 1990s [38]. Gradually, the resettlers' willingness to accept resettlement and the preference for urban resettlement have both increased with the land shortage and national urbanization tide $[47,85]$. Some resettlers even ask for the stock right of sharing economic benefits from hydropower development projects [47,85-87]. However, it is too heavy a burden for companies that run the dam projects or other development projects, not feasible in reality. More institutional innovations are actually needed and have undergone experiments $[88,89]$. In reality, to mitigate the conflicts caused by land deficiency and avoid the game of chicken for resettlers, the government of China has upgraded the compensation standard more than four times [8] and has also opened access to urbanization resettlement in many places [90]. These changes have also been found in our surveyed families during the post-relocation stage.

Meanwhile, another significant change is the livelihood diversification or the lifestyle change for resettlers from previous land-dependent agricultural ways to multi-sourced money-making ways in our case. Similar to what was reported in documents [89], the lifestyle change makes previous living skills not enough for resettled families. Different from the simple farming way of life, resettlers have to learn more professional skills and upgrade their educational levels to gain new job opportunities and thus increase their family income and personal capacity to better integrate into new local societies. Yet, this process happens in a time-consuming way. These are reasons for the human assets to be reduced and financial assets to remain uncertain after the relocation.

Combing the results in Figures 3 and 4 suggests that there are fewer livelihood capital differences in DF than in the other two before and after resettlement. The social, financial, and physical assets are all increased in the DF region, which might imply that local resettlement costs less in the relocation process. Yet the total size of livelihood in the DF region is also smaller than in the HJD and QZSN regions.

In short, relocation dramatically changes resettlers' natural assets, creates challenges to human assets, and affects financial assets at varying degrees specific to the far-away resettlers in our study. Indeed, relocation changes the lifestyle of resettlers profoundly because they have to change their farming-dependent living way and adapt to their new job opportunities, new houses, new schools, new roads, and social-ecological system, etc. This finding matches the report of Liu et al. [91]. However, the relocation has imposed mild positive effects on physical assets due to the investment of resettlement funds and other investments via the push-pull force of the compensation funds [27]. Interestingly, resettlers' social assets decreased when they were relocated nearby for unknown reasons. Further interviews are needed to explain the observed phenomena.

\subsection{The Impetus behind the PReS Policy Implementation in Early Stage}

Figure 5 suggests that there is a set of complete operational mechanisms hidden behind the PReS policy; this policy has successfully reversed the shrinkage tendency of household livelihood capital in all three reservoir regions after resettlement. Although there is no big enlargement for livelihood capital, the so-called benefits-sharing of $600 \mathrm{RMB} /$ person/year 
from water resources has effectively upgraded the natural assets, which balance the 5 -assets pentagon shortly after implementation of the policy (only in this paper).

First of all, the preferential principle of the PReS policy [92] has emphasized reservoir resettlers' priority in many aspects since the early stage (within the first five years) after relocation. Synergy with other policies, such as poverty alleviation policies and Rural Revitalization policy, the PreS helps to overcome the difficulties on resettlers' sustainable livelihood capital. To make the principle concrete and continuously effective, the resettler rosters and family files are required to be set in county-level Ecological Migration Bureau or local resettler management department since the very beginning of resettlers' new life in relocated places.

Second, Many efforts have thus been devoted not only to the whole process of reservoir resettlement from the project feasibility study stage, the compensation stage, to the post-support period after resettlement [8] but also to the institutional system that stimulates grass-roots staffs and organizations to be involved into providing supports to resettlers. The resettlement management department in Guizhou province, as the most typical and very unique example in China, has been independent of the provincial-level Water Conservancy Department and has focused on the resettler support issues since 2001. In 2018, the crucial moment for massive relocation, this Bureau, together with the Provincial Development and Reform Department, had jointly established a new provincial management unit, called Guizhou Ecological Resettlement Bureau (GZ-ERB) [93,94] covering reservoir-related, poverty-alleviation resettlement, and other hazards-avoidance resettlement which is the only provincial-level Ecological Migration Bureau in China, maybe in the world up-todate. It is such an institutional system that plays important roles $[95,96]$ in the effective improvement shortly after the relocation.

In the same year of 2018, GZ-ERB launched unique institutional system guidance to optimize ecological compensation standards, monitor the resettlement process, improve resettlers' livelihood capital, and prevent the impoverishment of the special population, such as the disabled, insane, the old without family support, chronic patient, and others. When implementing PReS policy, GZ-ERB has also initiated organization management strategies to inspire its subordinated municipal- and county-level governments to be actively involved in resettlement and poverty prevention work for the resettlers. For example, the Chair of Ecological Bureau at the provincial-, municipal-, county-, township-level is officially appointed as a vice-chair leader in its corresponding government. This treatment is a political promotion in practice to the critical person in charge of the resettlement work. This gives him not only personal dynamic but also organizational convenience or authority to facilitate the resettlement management work.

Third, the special funds for resettlement are allocated by the central government of China, coordinated by the provincial government, and managed at the county level. In provinces such as Guizhou, the provincial government has many regulative innovations on resettlement work according to secure the implementation of PReS policy because the massive poverty risk and fragile local environment have created great pressure on the governments at all levels to Guizhou reservoir development, including the WJ river basin $[97,98]$.

At last, considering the pulling effect of infrastructure construction and human assets on agricultural industry development $[69,90,99]$, local governments have emphasized the importance of physical assets and human assets rebuilt since the early stage of resettlement. In fact, the infrastructure construction optimizes local transportation, stimulates economic growth, upgrades life quality, and creates job opportunities. Which has gradually changed almost every aspect of household livelihood optimization, modifies livelihood diversity, and finally helps to maintain the sustainable livelihood for resettlers.

\subsection{Impacts of the PReS Policy in Time Line}

The PReS policy has imposed positive impacts on the overall growth of resettlers' livelihood capital across the 20-years time span before and after the policy implementation (see 
Figure 5 and Table 2). This growth is close to a positive linear curve ( $y=0.4285 x+1.9708$, $\mathrm{R}^{2}=0.9646$ ) with a jet-lag-like lower growth rate point in the early stage after the policy.

Yet, different assets of the livelihood capital own diversified variation characters in three resettlement regions. The physical and social assets display the tendency of continuously growing and are possibly the driving factors for resettlers' livelihood capital growth These findings are unlike previous reports because social assets mostly develop slowly and are relatively slow to be changed in most studies [69,90]. Differently, human assets reveal a cumulative effect for 10 to 15 years in our study. With the improvement of the educational conditions for the second generation of resettlers, the admitted ratio to universities had achieved a leap after the year 2014. The education level and livelihood diversification level in some families have, therefore, significantly improved since around 2018. This educational level change has led to a stable human asset upgrading and promising livelihood capital improvement for such relocated families.

The development funds of the PReS have successfully promoted livelihood diversification and brought the share of benefits from projects profits to some resettlers and their families, which protects resettlers from household livelihood unbalanced and financial assets decreased due to the limitation of the natural resource losses [99]. Compared to previous reports [100] that agriculture-industrialization-development has imposed significantly positive effects on farmers' livelihood capital through enhancing human, social and financial assets. Meanwhile, it is insufficient to affect natural and physical assets [100].

In our case, the institutional systems have performed quite well in improving physical assets, social, and human assets. However, due to the unstable performance of financial assets, the pull effects of development funds have not yet played a significant role in promoting the expansion of resettlers' livelihood capital.

Furthermore, an important part of PReS policy is the cash subsidy of $600 \mathrm{RMB} /$ person/ year $[101,102]$. Although the value of fixed cash subsidy continuous to depreciate becomes less meaningful due to currency inflation. This is still important for $20 \%$ of low-income, vulnerable resettler families.

In 2000, $600 \mathrm{RMB}$ was near twice the amount of the annual personal income of the local farmer on average. Yet, in 2020, for $63.33 \%$ of the surveyed resettlement families, this amount occupies less than $5 \%$ of their family income averagely, which is trivia for their total financial assets. Some richer resettlers who owned relatively stable occupations call it a "vegetable subsidy" in a humorous way which suggested the limited amount of less than two yuan per day only helps to buy a vegetable dish for such families. Totally different for $20 \%$ of the marginal relocated population that is shaving at the poverty line, including the families of the old, weak, sick, and disabled, the annual income from the $600 \mathrm{RMB}(\approx \$ 94.32)$ still accounts for more than $10 \%$ of their income. If the money is not paid after 20 years due to policy reasons, such families with weak earning power will be affected more seriously. For $16.67 \%$ of families whose subsidy of $600 \mathrm{RMB}(\approx \$ 94.32)$ accounts for $5-10 \%$ of their annual income, the impacts of policy deduction are directly related to the development of these families. If the population structure is relatively young, the overall income may increase, and the impact of funds may be reduced; conversely, if family members age, there may be a risk of returning impoverishment.

\subsection{Impacts of the PReS Policy on Livelihood Diversity}

According to documents, basic infrastructure construction helps livelihood diversity gradually be improved and thus helps to overcome the livelihood vulnerability in front of risks such as climate change and other social issues [103-106]. Employment has been another important driving factor to improve annual income and livelihood diversity for rural families $[102,103]$. We have similar observations.

In our case, the institutional system of resettlement secures the construction of the physical assets and creates both local and external job opportunities. First, implementing the post-supporting projects has created more local job opportunities for reservoir resettlers in surveyed regions. Second, the social connection between western-to-eastern cities 
encouraged by the policy has opened many external job opportunities to resettlers in the WJ river basin, southwest China.

We observed the fact that physical assets have started to improve since the first 5-years after the policy implementation (see Figure 5), which keeps pace with the improvement of livelihood diversity for the relocated population. Figure 8 has implied that the PReS policy has increased the ratio of multi-sourced income families in the year 2020 in the selected resettlement regions. Figure 9 implies that livelihood diversification is improved after the policy.

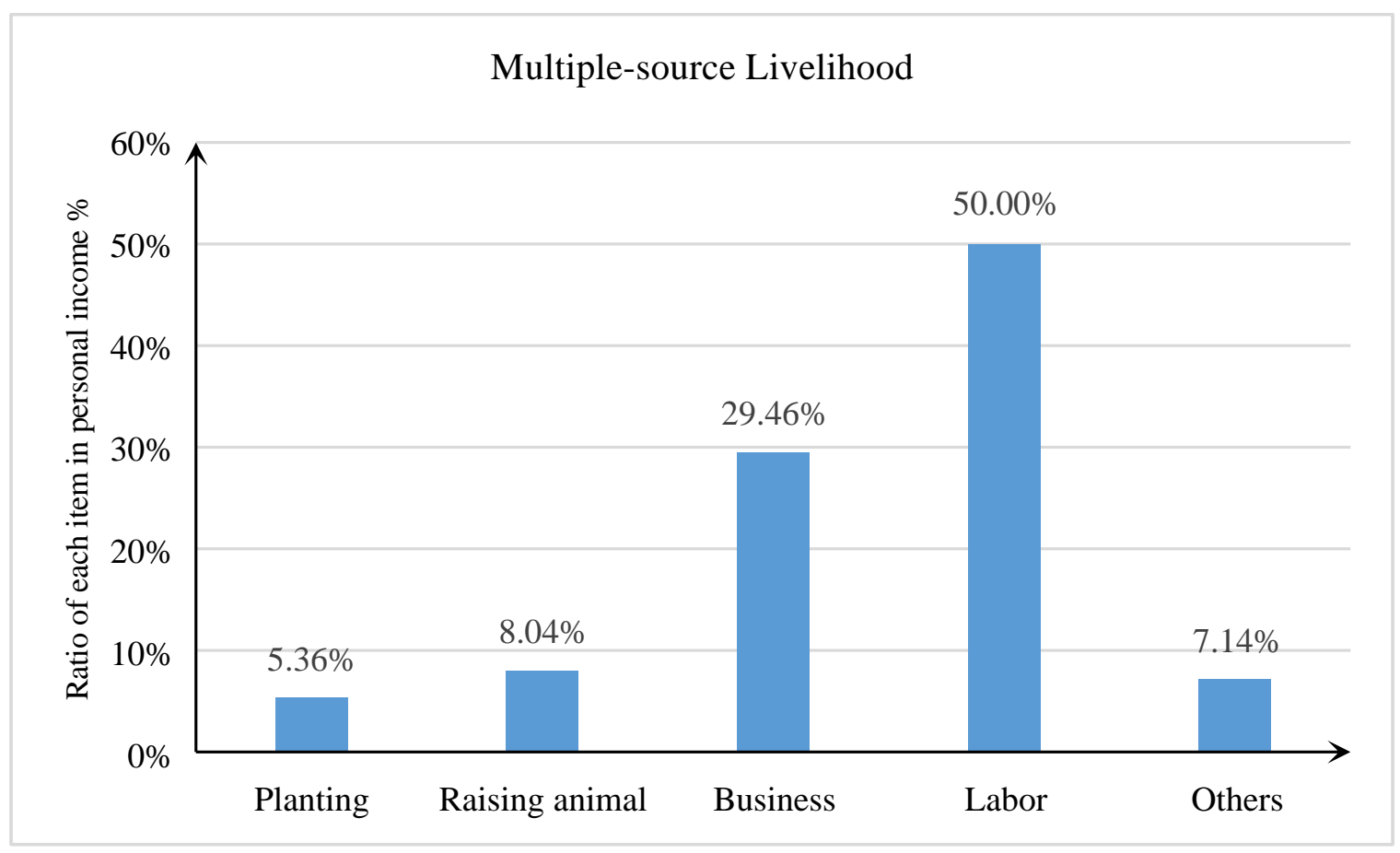

Figure 9. Impacts of the PReS policy on income diversity.

For the resettlers, working as labor or running a small rural business rather than solely farming became their major choice in the year 2020. The new dominant income component for relocated families is to work as laborers, which ranks first among five of the surveyed typical income sources and contributes to $50.0 \%$ of the annual income on average. The rural business contributes to $29.46 \%$ of the income average and ranks second of importance on the contribution board. While, due to land resources reduction or loss, the ratio of traditional farming activities has remained as little as $5.36 \%$ and $8.04 \%$ to the resettlers annual income. Other types of income have occurred only $7.14 \%$ of the total family income. In short, $86.63 \%$ of the family income comes from non-farming activities, and as much as $85.75 \%$ of the resettlers have changed their lifestyle from farming-dependent to multiplesourced under the supervision of the PReS policy. These ratios are all higher than farmers in north China in previous reports [86] and show similar trends of urbanization preference in non-farming rural families [95].

\subsection{Trends of Resettlement Policies}

Since the 1990s, the land re-allocation to resettlers in the rural area became increasingly difficult [85]. Accordingly, the resettlers' willingness to accept resettlement has increased $[27,47]$. Some resettlers even ask for the stock right of sharing economic benefits from hydropower development projects $[27,47]$. However, it is too heavy a burden for companies that run the dam projects or other development projects. Thus, it is not feasible in reality. 
Combing with the migrating tide and the urbanization trend, more and more young resettlers prefer urban resettlement [84]. To avoid the game of chicken for resettlers, the government of China has upgraded the compensation standard more than four times [8] and opened access to urbanization resettlement in many places [84].

Documents tell the trend of resettlement diversification. With financial assets and social assets increasing, farmers tend to sell out their land assets; reversely, with the natural and human assets increasing, farmers tend to buy land assets [95].

Therefore, in the next stage, more flexible policies are needed to satisfy the diversified needs of different types of resettlers.

\subsection{A Dark Point of the PReS Policy - "The Phenomena of 40-to-50-Years-Old Resettler Group"}

Through the investigations, we have observed that there are some special phenomena among the resettlers groups which need enough attention to be paid by the policy-makers. Otherwise, the livelihood sustainability of reservoir resettlers may be threatened. One of them is called "the 40-50 aged phenomenon". It has not yet been found and reported currently.

During the process of implementation of the PReS policy, the second-generations would receive much better educational opportunities than their parent resettlers in the new resident system. When they became mature, their family would be rewarded by the demographic dividend because many of those young generations may support their family members according to traditional Chinese culture. Thus, the new generation forms better human resources, achieves better job access, and feedback their families with the improved and stable income after 5 to 20 years of the PReS implementation. In this case, the whole family would benefit continuously from the PReS policy in the long run.

However, those families with members aged 40-50 (middle-aged people) whose children have reached adulthood at the time after relocation. Who are incapable of directly receiving this demographic dividend because their children have already missed the educational chances. After the expiration of the 20-year policy, the main members of these families will become older at the age of 60-70. They would have no ability to compete in the labor market or run a business in the next 20 years. With only the pension and social insurance, their living standards would possibly decline dramatically, and they would even constitute a group of resettlers with a high risk for impoverishment.

With a longer social life expectancy, this "40-50 aged phenomenon" would last for a rather long time in the future. Therefore, for this type of specific resettlers who face potential impoverishment risk, the timeliness of the PReS policy has reasons to be re-considered or extended.

\section{Conclusions}

The reservoir resettlement has caused livelihood capital decline, and lifestyles change to the resettlers. Two crucial reasons are the losses of land assets and population relocation. These facts lead to the changes of resettlers' livelihood diversification and lifestyle change, which puts forward new requirements for the improvement of job skills and personal capability.

The PReS policy may reverse the shrinkage tendency of livelihood capital through the relatively rapid improvement on physical, social, and financial assets since the early stage of the policy implementation, and it may gradually improve the human assets in regard to its slow-release character and make up for the natural assets with innovated strategies such as natural resource securitization, if possible.

Through this study, it is safe to conclude that the PReS policy has contributed to the balance of livelihood capital for resettlers from all aspects but faces multiple challenges. In surveyed regions, the PReS policy has helped to form a stable mechanism to support resettlers' livelihood capital improvement continuously through its unique fund's collection strategy and push-pull power in driving the institutional systems since the early stage of the post resettlement support, and thus improve the overall livelihood capital of resetter 
household. Synergy with other policies, the PReS has the potential to help overcome many difficulties in sustaining the livelihood capital of resettlers'.

However, the project funds have not yet fully played a significant role in improving sustainable livelihood. Thus, the income sources are still too simple, which is not conducive to the sustainability of the majority of resettlers groups.

Other main challenges of the PReS policy are, firstly, the 20 years expiration of the current PReS policy needs to be extended at least for vulnerable groups of resetters to avoid impoverishment in the near future. Ending the PReS policy by the 20th year may lead to the rapid shrinkage of the livelihood capital, pushing 40 to 50 years old laborers and other vulnerable families to risk re-impoverishment. Secondly, the fixed cash subsidy contributes little and diminishes under inflationary pressure. Thirdly, more institutional or policy innovations over the post-subsidy or benefit-sharing are needed to sustain the livelihood for vulnerable resettlers. Last, considering equity, those relocated in urban areas are beyond the institutional system of the PReS policy. If they confronted impoverishment issues, the cross-political departments' post-stage support could not be equally provided according to the current policy setting.

In short, the PReS policy has reasons to extend for specific resettler groups under current situations. Meanwhile, more policy innovations regarding asset securitization and impoverishment prevention are needed.

Our findings would help but not be limited to solving reservoir resettlement issues. They can be extended to use and apply for planning, monitoring, assessing, and implementing in the post support stage for diversified ecological or development-caused resettlement. The use of the policy is not limited to China issues. Instead, it is recommended to use in solving global resettlement issues regarding sustainable livelihood for the relocated.

Author Contributions: Conceptualization, Y.X.; methodology, software, validation, Y.X. and Y.D.; formal analysis, Y.X. and Y.D.; investigation, Y.X., Y.D. and G.S.; resources, Y.X.; writing—original draft preparation, Y.X. and Y.D.; writing-review and editing Y.D and G.S.; visualization, Y.D.; supervision, G.S.; project administration, Y.X. and G.S.; funding acquisition, G.S. All authors have read and agreed to the published version of the manuscript.

Funding: This research was funded by the Key Research Project of the National Foundation of Social Science of China (Fund No. 21\&ZD 183), Community Governance and Post-relocation Support in Cross District Resettlement.

Institutional Review Board Statement: Not applicable.

Informed Consent Statement: Not applicable.

Data Availability Statement: Not applicable.

Conflicts of Interest: The authors declare no conflict of interest.

\section{References}

1. Shi, G. Sustainable hydropower and public connition. China Three Gorges 2012, 12, 64-66. (In Chinese)

2. Zhengang, S. Overview of general survey of basic conditions of water conservancy projects. China Water Resour. 2010, 11, 4. (In Chinese)

3. Anonymous. China's dam construction level ranks first in the world. Build. Mater. Dev. Orientat. 2009, 3, 29. (In Chinese)

4. Sun, Z.; Zhang, L.; Duan, Z. Quantity and distribution of reservoir projects in China. China Water Resour. 2013, 7, 10-11. (In Chinese)

5. Yao, Y. 70 Years of Land Acquisition and resettlement for Water Conservancy and Hydropower Projects in China. Water Power 2020, 46, 8-12. (In Chinese)

6. Shi, G.; Jiang, T.; Sun, Z. Evolution of Land and Resettlement Laws in China: Setting New Standards. In Resettlement in Asian Countries: Legislation, Administration and Struggles for Rights; Zaman, M., Nair, R., Shi, G., Eds.; Routledge/Taylor Francis: London, UK, 2022. [CrossRef]

7. Huang, H.; Shi, G. Causes and Cope in the remaining problems of reservoir resettlement. Water Econ. 2000, 3, 50-55.

8. Gu, M.; Chen, S.; Xun, H.; Fan, Z.; Chen, S. Exploration, Planning and Management of the Remaining Problems of Reservoirx Resettlement; Hohai University Press: Nanjing, China, 2000. (In Chinese) 
9. Shi, G.; Zhou, J.; Yu, Q. Resettlement in China. In Impacts of Large Dams: A Global Assessment; Springer: Berlin/Heidelberg, Germany, 2012; pp. 219-241. [CrossRef]

10. Fernandes, W. Power and powerlessness: Development projects and displacement of tribal. Soc. Action 1995, 41, 243-270.

11. Koch-Weser, M.; Guggenheim, S. Social Development in the World Bank: Essays in Honor of Michael Cernea; Springer Nature: Cham, Switzerland, 2021; p. 235. [CrossRef]

12. Ota, A. Countering the Impoverishment Risk: The Case of the Rengali Dam Project Involuntary Displacement in the Dam Projects; Prachi Prakashan: New Delhi, India, 1996.

13. Mathur, H. The impoverishment risk model and its use as a planning tool. In Development Projects and Impoverishment Risk: Resettling Project-Affected People in India; Mathur, H.M., Marden, D., Eds.; Oxford University Press: New Delhi, India, 1998; pp. $1-55$.

14. Zaman, M.; Khatun, H. Development Induced Displacement and Resettlement in Bangladesh: Case Studies and Practices; Nova Science Publishers: New York, NY, USA, 2017; pp. 1-224.

15. Zaman, M.; Nair, R.; Shi, G. (Eds.) Resettlement in Asian Countries: Legislation, Administration and Struggles for Rights; Routledge/Taylor Francis: London, UK, 2022.

16. Cernea, M. Understanding and preventing impoverishment from displacement: Reflections on the state of knowledge. J. Refug. Stud. 1995, 8, 245-264. [CrossRef]

17. Cernea, M. The risks and reconstruction model for resettling displaced populations. World Dev. 1997, 25, 1569-1589. [CrossRef]

18. World Bank. Involuntary Resettlement. OD 4.30. 1990. Available online: http:/ /www.worldbank.org/ (accessed on 15 October 2021).

19. World Bank. Involuntary Resettlement, OP/BP 4.12. 2002. Available online: http://www.worldbank.org/ (accessed on 15 October 2021).

20. World Bank. Environment and Social Framework. 2018. Available online: http://www.worldbank.org/ (accessed on 15 October 2021).

21. State Council of PRC. The Regulation on Land Acquisition and Resettlement Compensation in Large and Medium-Scale Hydraulic and Hydropower Projects; Decree No. 74.1991; State Council of PRC: Beijing, China, 1991; Available online: http://gtj.yueyang.gov.cn/ 302400/30260/43314/content_1363066.html (accessed on 10 October 2021).

22. GOI. The Right to Fair Compensation and Transparency in Land Acquisition, Rehabilitation and Resettlement Act2013; Department of Land Resources, Ministry of Rural Development, Government of India: New Delhi, India, 2013.

23. Shi, G. Reservoir Resettlement System Planning Theory and Application; Hohai University Press: Nanjing, China, 1996; pp. 181-187. ISBN 7-5630-0802-0. (In Chinese)

24. Shi, G.; Hu, W. Comprehensive evaluation and monitoring of displaced persons standard of living and production. In Proceedings of the International Senior Seminar on Resettlement and Rehabilitation; NRCR, Ed.; Hohai University Press: Nanjing, China, 1995; pp. 248-254.

25. ADB (Asian Development Bank). Handbook on Involuntary Resettlement: A Guide to Good Practice; Asian Development Bank: Manila, Philippines, 1998.

26. Wilmsen, B.; Webber, M.; Duan, Y. Involuntary rural resettlement: Resources, strategies, and outcomes at the three Gorges Dam, China. J. Environ. Dev. 2011, 20, 355-380. [CrossRef]

27. Shi, G. Preliminary study on reservoir resettlement. Prog. Water Conserv. Hydropower Technol. 1999, 47-48. (In Chinese)

28. Kong, L.; Shi, G. Resettlement mode on rural resettlers as shareholder of hydropower projects. Yangtze River Basin Resour. Econ. 2008, 17, 185-189.

29. Partridge, W.L.; Halmo, D.B. Resettling Displaced Communities: Applying the International Standard for Involuntary Resettlement; Lexington Books: Lanham, MD, USA, 2021.

30. Cernea, M. Risks, safeguards, and reconstruction: A model for population displacement and resettlement. In Risks and Reconstruction. Experiences of Resettlers and Refugees; Cernea, M., McDowell, C., Eds.; The World Bank: Washington, DC, USA, 2000; pp. 11-55. [CrossRef]

31. Cernea, M. Risks and Reconstruction-Experiences of Resettlers and Refugees; The World Bank: Washington, DC, USA, 2000.

32. Shi, G. Comparing China's and the World Bank's resettlement policies over time: The ascent of the 'resettlement with development' paradigm. In Challenging the Prevailing Paradigm of Displacement and Resettlement: Risks, Impoverishment, Legacies, Solutions; Cernea, M.M., Maldonado, J.K., Eds.; Routledge: Abington, NY, USA, 2018; pp. 45-56.

33. Shi, G.; Yu, F.; Wang, C. Social assessment and resettlement policies and practice in China: Contributions by Michael M Cernea to development in China. In Social Development in the World Bank; Koch Weser, M., Guggenheim, S., Eds.; Springer: Berlin/Heidelberg, Germany, 2021; pp. 329-346. [CrossRef]

34. Wilmsen, B.; Adjartey, D.; van Hulten, A. Challenging the risks-based model of involuntary resettlement using evidence from the Bui Dam, Ghana. Int. J. Water Resour. Dev. 2019, 35, 682-700. [CrossRef]

35. Scudder, T.; Colson, E. For Prayer and Profit: The Ritual, Economic, and Social Importance of Beer in Gwembe District, Zambia 1950-1982; Stanford University Press: Redwood City, CA, USA, 1988.

36. Scudder, T. The Future of Large Dams: Dealing with Social, Environmental, Institutional and Political Costs; Earthscan: London, UK, 2005. 
37. Downing, T.; Garcia-Downing, C. Routine and dissonant culture: A theory about the psycho-socio-cultural disruptions of involuntary displacement and ways to mitigate them without inflicting even more damage. In Development and Dispossession: The Anthropology of Displacement and Resettlement; Oliver-Smith, A., Ed.; School for Advanced Research Press: Santa Fe, NM, USA, 2009; pp. 225-253. Available online: https://www.researchgate.net/publication/303213123 (accessed on 20 October 2021).

38. De Wet, C. Why do things so often go wrong in resettlement projects. In Moving People in Ethiopia: Development, Displacement and the State; Pankhurst, M., Pguet, F., Eds.; James Currey: Woodbridge, ON, Canada, 2009; pp. 35-48.

39. Zhu, W.; Shi, G. A discussion on the benefit-sharing mechanisms and methods for resettlement system. Water Conserv. Econ. 1995, 12, 58-61. (In Chinese)

40. Shi, G.; Chen, S.; Yuan, R.; Hu, W. Method in Analysis and Assessment of Living and Livelihoods Standard of Reservoir Resettlement. Water Conserv. Xuebao 1996, 62, 51-55. [CrossRef]

41. Shang, K.; Shi, G. Land Asset Securitization Resettlement Model for Rural Resettlars Induced by Hydropower Development Project China; Social Science Academic Press: Beijing, China, 2012; pp. 34-205. ISBN 978-7-5097-3555-8. (In Chinese)

42. Zhang, R.; Owen, J.; Kemp, D.; Shi, G. An applied framework for assessing the relative deprivation of dam-affected communities. Sustain. Dev. 2021, 30,1-15. [CrossRef]

43. Shi, G.; Chen, S.; Xing, H.; Xun, H. China Resettlement Policy and Practice; Ningxia People Press: Yinchuan, China, 2001. (In Chinese)

44. Cernea, M.; Mathur, H. Can Compensation Prevent Impoverishment? Reforming Resettlement through Investments (OUP Catalogue); Oxford University Press: Oxford, UK, 2007.

45. Duan, Y.; McDonald, B. From compensation to development: The application and progress of RwD in China. Ecol. Econ. 2008, 4, 317-356.

46. Cernea, M. Compensation and benefit sharing: Why resettlement policies and practices must be reformed. Water Sci. Eng. 2008, 1, 89-120. [CrossRef]

47. Koenig, D. Advantages and obstacles to retro-fitting benefit: Sharing after development-induced displacement and resettlement. Impact Assess. Proj. Apprais. 2021, 39, 417-428. [CrossRef]

48. Kong, L.; Shi, G.; Qiao, X.; Zeng, X. Hydropower resettlement mechanism based on the benefifit sharing perspective. Water Conserv. Hydropower Technol. 2007, 38, 62-64.

49. Koranteng, R.; Shi, G. Aalyzing the relevance of VRA resettlement trust fund as a benefit sharing mechanism. J. Sustain. Dev. 2018, 11, 99. [CrossRef]

50. Price, S.; Van Wicklin, W., III; Koenig, D.; Owen, J.; de Wet, C.; Kabra, A. Risk and value in benefit-sharing with displaced people: Looking back 40 years, anticipating the future. Soc. Chang. 2020, 50, 447-465. [CrossRef]

51. Xu, J.; Shi, G.; Li, B.; Fischer, T.; Zhang, R.; Yan, D.; Jiang, J.; Yang, Q.; Sun, Z. Skills' sets and shared benefits: Perceptions of resettled people from the Yangtze-Huai River Diversion Project in China. Impact Assess. Proj. Apprais. 2021, 39, 429-438. [CrossRef]

52. Wang, H.; Owen, J.; Shi, G. Land for equity? A benefit distribution model for mining induced displacement and resettlement. Bus. Strat. Environ. 2020, 29, 1-12. [CrossRef]

53. Yuefang, D.; Ali, S.; Bilal, H. Reforming Benefit-Sharing Mechanisms for Displaced Populations: Evidence from the Ghazi Barotha Hydropower Project, Pakistan. J. Refug. Stud. 2021, 24, 3511-3531. [CrossRef]

54. Shi, G.; Lyu, Q.; Shangguan, Z.; Jiang, T. Facing Climate Change: What Drives Internal Migration Decisions in the Karst Rocky Regions of Southwest China. Sustainability 2019, 11, 2142. [CrossRef]

55. Saychai, S.; Shi, G.; Yu, Q. Resettlement Policies and Implementation Management: A Case of Hydropower Resettlement Management in Laos. Int. J. Bus. Econ. Manag. 2016, 3, 25-32.

56. Yan, D.; Shi, G.; Hu, Z.; Wang, H. Resettlement for the Danjiangkou dam heightening project in China: Planning, implementation and effects. Int. J. Water Resour. Dev. 2017, 33, 609-627. [CrossRef]

57. Yan, D.; Wang, M.; Wang, H.; Shi, G. Policy and implementation of land-based resettlement in China (1949-2014). Int. J. Water Resour. Dev. 2018, 34, 453-471. [CrossRef]

58. Yu, Q.; Shi, G. Stakeholder Participation in Rural Land Acquisition in China: A Case Study of the Resettlement decision-Making Process. In Making a Difference? Social Assessment Policy and Praxis and its Emergence in China; Berghahn Books: New York, NY, USA, 2015; pp. 242-261.

59. Yu, Q.; Lei, Y. Constructing the Participation Mechanism of Reservoir Resettlement; Springer: Berlin/Heidelberg, Germany, 2009; pp. 1489-1495. [CrossRef]

60. Wang, N.; Shi, G.; Zhou, X. To move or not to move: How farmers now living in flood storage areas of China decide whether to move out or to stay put. J. Flood Risk Manag. 2020, 13, e312609. [CrossRef]

61. Peng, S.; Shi, G.; Zhang, R. Social stability risk assessment: Status, trends and prospects-A case of land acquisition and resettlement in the hydropower sector. Impact Assess. Proj. Apprais. 2021, 39, 379-395. [CrossRef]

62. Zhang, R.; Shi, G.; Wang, Y.; Zhao, S.; Ahmad, S.; Zhang, X.; Deng, Q. Social impact assessment of investment activities in the China-Pakistan economic corridor. Impact Assess. Proj. Apprais. 2018, 36, 331-347. [CrossRef]

63. Zhang, R.; Andam, F.; Shi, G. Environmental and social risk evaluation of oversea investment under the China-Pakistan economic corridor. Environ. Monit. Assess. 2017, 189, 253. [CrossRef] [PubMed] 
64. Wang, H. Research on Problems and Countermeasures for Urbanization of Reservoir Resettlement in Guizhou Province. Adv. Mater. Res. 2014, 1065-1069, 629-633. [CrossRef]

65. Zhao, X. Discussion on joint stock resettlement of water conservancy and hydropower projects. People's Yangtze River 2008, 83-85. [CrossRef]

66. Xu, X.; Wang, X.; Zhao, Y. Comprehensive Evaluation of Implementation Effect on Later-Period Supportive Policy of Reservoir Resettlement Based on ANFIS. Adv. Mater. Res. 2014, 912-914, 1874-1878. [CrossRef]

67. Chen, X.; Vanclay, F.; Yu, J. Evaluating Chinese policy on post-resettlement support for dam-induced displacement and resettlement. Impact Assess. Proj. Apprais. 2021, 39, 396-404. [CrossRef]

68. Downing, T.E.; Shi, G.; Zaman, M.; Garcia-Downing, C. Improving Post-Relocation Support for People Resettled by Infrastructure Development. Impact Assess. Proj. Apprais. 2021, 39, 357-365. [CrossRef]

69. Hamilton, R. Involuntary Resettlement in Development Projects: Policy Guidelines in World Bank-Financed Projectsby Michael, M. Cernea. Am. Anthropol. 1990, 92, 806-807. [CrossRef]

70. Downing, T. 'Mitigating social impoverishment when people are involuntarily displaced'. In Understanding Impoverishment: The Consequences of Development-Induced Displacement; McDowell, C., Ed.; Berghahn Books: Oxford, UK, 1996.

71. Dowell, C.; Haan, A. Migration and Sustainable Livelihoods: A Critical Review of the Literature; Berghahn Books: Oxford, UK, 1997.

72. Karki, S. Sustainable Livelihood Framework: Monitoring and Evaluation. Int. J. Soc. Sci. Manag. 2021, 8, 266-271. [CrossRef]

73. Li, H.; Huang, J.; Wang, W. The Sustainable Development Assessment of Reservoir Resettlement Based on a BP Neural Network. Int. J. Environ. Res. Public Health 2018, 15, 146.

74. Huang, J. Wujiang River Basin Research; China Science and Technology Publishing House: Beijing, China, 2007; pp. 42-45.

75. Basic Information of Wujiang Waterway (Guizhou Section). Wujiang Waterway Administration Bureau of Guizhou Province. 24 July 2015. Available online: https://baike.baidu.com/item/\%E4\%B9\%8C\%E6\%B1\%9F/4733?fr=aladdin (accessed on 16 May 2020).

76. Historical Changes of Wujiang River. Colorful Guizhou Network. 15 June 2017. Available online: https://zhidao.baidu.com/ question/1833812312094464420.html (accessed on 16 May 2020).

77. Wujiang Gallery. Colorful Guizhou Network. 18 December 2014. Available online: https://baijiahao.baidu.com/s?id=17069689 $88913570861 \mathrm{wfr}=$ spiderfor $=\mathrm{pc}$ (accessed on 16 May 2020).

78. XiaoCong, H.; Lisheng, Z.; Lingzhi, Y. Study on flood control operation problems and Countermeasures in Wujiang River Basin. People's Yangtze River 2018, 49, 5.

79. Zhang, M.; Zhang, X.; Yu, K. Hydrological characteristics of the Wujiang River basin. Hydrology 1999, 19, 53-56.

80. Shaoliang, D. Building green hydropower. China Electr. Power Enterp. Manag. 2008, 1, 82-84.

81. Junli, W.; Ying, G. Dynamic control analysis of flood limit water level of Dongfeng reservoir. Huazhong Electr. Power 2006, 41-48. (In Chinese)

82. Campbell, B.; Sayer, J.; Frost, R.; Vermeulen, S.; Ruiz, P.; Cunningham, A.; Prabhu, R. Assessing the performance of natural resource systems. Conserv. Ecol. 2001, 5, 22. Available online: http://www.consecol.org/vol5/iss2/art22/ (accessed on 16 May 2020).

83. Carney, D. Sustainable livelihoods Approaches: Progress and possibilities for change. In Department for International Development; DFID: Toronto, ON, Canada, 2003.

84. Qian, C. Local livelihood under different governances of tourism development in China-A case study of Huangshan mountain area. Tour. Manag. 2017, 61, 221-233. [CrossRef]

85. Shi, G.; Kong, L. Stakeholder analysis and ownership rights realization of hydropower development enterprises. Nanjing Soc. Sci. 2008, 1, 37-42. (In Chinese)

86. Zhou, X.; Shi, G.; Wang, H. Study on Urbanization Resettlement for Rural Displaced Persons of Reservoir Project; Social Sciences Academic Press: Beijing, China, 2018. (In Chinese)

87. Jian, H.U.; Xi, Y.E. Discussion on the Confirming Method of Line-outside Extended Relocation of Population in the Construction of Large and Medium-sized Water Resources and Hydropower Projects. Water Power 2015, 41, 19-26. (In Chinese)

88. Shi, G.; Shang, K. Land-asset-securitization: An innovative appreach to distingtuish between benefit-sharing and compensation in hydro-power development. Impact Assess. Proj. Apprais. 2021, 39, 405-416. [CrossRef]

89. Yu, W. Policy Innovation of Reservoir Resettlement under Urban-Rural Integration; Social Sciences Academic Press: Beijing, China, 2018; pp. 85-116. (In Chinese)

90. Han, X.; Shi, G.; Sun, Z.; Zhang, H. Can China's reservoir resettlement promote urbanization? Case Study 2015, $35,73-94$.

91. Liu, H.; Hao, H.; Hu, X.; Du, L.; Zhang, Z.; Li, Y. Livelihood Diversification of Farm Households and Its Impact on Cultivated Land Utilization in Agro-pastoral Ecologically-vulnerable Areas in the Northern China. Chin. Geogr. Sci. 2020, 30, $279-293$. [CrossRef]

92. Tao, J. Discussions on the compensation principles and support policies of the development resettlement of Three Gorges Project. Water Power 2001, 167, 65-92. (In Chinese)

93. The Introduction of Guizhou Ecological Migration Bureau. Available online: https://baike.baidu.com/item/\%E8\%B4\%B5\%E5

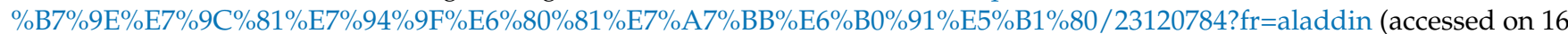
May 2020). 
94. The Report on Listing Ceremony of Guizhou Ecological Migration Bureau. Available online: http://stymj.guizhou.gov.cn/ ZWGK/ZDGK/GZYW/TPXW/201911/t20191125_17026330.html (accessed on 16 May 2020).

95. Bin, C.; Long, Z. Global migration governance and China's role from the perspective of "community with a shared future for mankind". J. Renmin Univ. China 2019, 33, 83-93. (In Chinese)

96. Gizaw, S. Resettlement Revisited: The Post-Resettlement Assessment in Biftu Jalala Resettlement Site. Ethiop. J. Bus. Econ. 2015, 3, 22-57.

97. Xiong, K.; Bai, L.; Peng, X. Research on changes of land-use in different scale in karst mountain. Carsologica Sin. 2005, 89, 949-950. (In Chinese)

98. Wang, S.; Yangbing, L.; Ruiling, L.I. Karst rocky desertification: Formation background, evolution and comprehensive taming. Quat. Sci. 2003, 23, 657-666.

99. Zhang, J.; Zhang, R.; Xu, J.; Wang, J.; Shi, G. Infrastructure Investment and Regional Economic Growth: Evidence from Yangtze River Economic Zone. Land 2021, 10, 320. [CrossRef]

100. Yang, H.; Huang, K.; Deng, X.; Xu, D. Livelihood Capital and Land Transfer of Different Types of Farmers: Evidence from Panel Data in Sichuan Province. China Land 2021, 10, 532. [CrossRef]

101. Liu, M.; Feng, X.; Wang, S. Does poverty-alleviation-based industry development improve farmers' livelihood capital? J. Integr. Agric. 2021, 20, 915-926. [CrossRef]

102. Shi, P.; Vanclay, F.; Yu, J. Post-Resettlement Support Policies, Psychological Factors, and Farmers' Homestead Exit Intention and Behavior. Land 2022, 11, 237. [CrossRef]

103. Mcleman, R.; Hunter, L. Migration in the context of vulnerability and adaptation to climate change: Insights from analogues. Wiley Interdiscip. Rev. Clim. Chang. 2010, 1, 450-461. [CrossRef]

104. Lin, K.; Chang, C. Everyday crises: Marginal society livelihood vulnerability and adaptability to hazards. Prog. Dev. Stud. 2013, 13, 1-18. [CrossRef]

105. Etea, B.; Zhou, D.; Abebe, K.; Sedebo, D.A. Is income diversification a means of survival or accumulation? Evidence from rural and semi-urban households in Ethiopia. Environ. Dev. Sustain. A Multidiscip. Approach Theory Pract. Sustain. Dev. 2020, 22, 5751-5769. [CrossRef]

106. Tran, V.; An-Vo, D.; Cockfield, G.; Mushtaq, S. Assessing Livelihood Vulnerability of Minority Ethnic Groups to Climate Change: A Case Study from the Northwest Mountainous Regions of Vietnam. Sustainability 2021, 13, 7106. [CrossRef] 